\author{
Research Article \\ www.ijrap.net (ISSN:2229-3566)
}

\title{
ANTINOCICEPTIVE ACTIVITY OF MAGNOLIA GRANDIFLORA LINN. LEAVES
}

Ramyashree $\mathrm{C}^{*}$, Hemalatha Kamurthy

Department of Pharmacognosy, Acharya and BM Reddy College of Pharmacy, Bangalore, Karnataka, India

Received on: 262/0/20 Accepted on: 10/10/20

\author{
*Corresponding author \\ E-mail: ramyashree.135@gmail.com
}

DOI: $10.7897 / 2277-4343.1106184$

\begin{abstract}
Magnolia grandiflora (Magnoliaceae) is an evergreen tree with fragrant and showy flowers native to southeastern USA but widely cultivated all over the world and used in cosmetics industry in treatment of skin diseases. To estimate the different extracts of Magnolia grandiflora leaves by performing pharmacological screening of analgesic activity (Hot plate method and tail immersion method). In the present study the two methods were performed the mice was placed on a hot plate maintained at the temperature of $55 \pm 1{ }^{\circ} \mathrm{C}$ and the pain reaction time (PRT) or latency period determined with a stop watch was recorded and then about $2-3 \mathrm{~cm}$ of the tail of each of the mice was dipped into a water bath containing warm water maintained at a temperature of $50 \pm 1^{\circ} \mathrm{C}$ and the time taken for the mice to flick its tail or withdraw it from the warm water known as the pain reaction time (PRT) was recorded. Here, we report on the Pharmacological investigation of different extracts of Magnolia grandiflora Linn leaves. The results were demonstrated on that ethyl acetate extract $(\mathrm{P}<0.01)$ exhibited significant dose dependent analgesic activity in all tested models for analgesia. The time course for analgesia revealed maximum activity after $30 \mathrm{~min}$ in both tail immersion and hot plate methods, which was prolonged to 24 hours. The study concludes that the ethyl acetate extract from leaves of Magnolia grandiflora possess analgesic activity at doses $250,500 \mathrm{and} 100 \mathrm{mg} / \mathrm{kg} \mathrm{I.} \mathrm{p.}$
\end{abstract}

Keywords: Magnolia, Extracts, Analgesic activity, Magnolia grandiflora, Phytoconstituents, Hot plate and Tail immersion method.

\section{INTRODUCTION}

Southern Magnolia (Magnolia grandiflora) (Magnoliaceae) is a magnificent slow to moderate growing, evergreen tree. The leaves are simple, pinnate venation, smooth, waxy and oval to elliptic shape $^{1}$. Although there are some 250 species in the genus, Magnolia grandiflora is a dense, multi-branched evergreen tree, size 60 and 80 feet tall ${ }^{2}$. Magnolia grandiflora Linn. Plant is wildly used in Asian as a traditional herbal medicine and Chinese medicine for the treatment of colds, headaches, diarrhea, abdominal diseases and stomachache. A decoction of the bark of Magnolia grandiflora (Katlaha) was used by Indians as a remedy against itching due to 'prickly heat' and reported as a febrifuge ${ }^{3}$. The plant has also been used for the treatment of diarrhea and arthritis ${ }^{4}$. Various classes of compounds such as sesquiterpenoids, coumarins, glycosides, alkaloids and other compounds have been reported from this plant $^{5}$ and also, they have been reported on flowers and leaves of aqueous extracts exhibit cardiovascular effects and as anticonvulsant activity. However, few documented literatures on phytoconstituents, scientific studies are reported from flower and root parts from this plant. But as per our knowledge, there is no documented literature of isolation and pharmacological activity of any phytoconstituents of Magnolia grandiflora leaves. Hence, the present study elucidates the activities from the different crude extracts of leaves of Magnolia grandiflora on the basis of various pharmacological activities.

\section{MATERIALS AND METHODS}

\section{Plant material}

Leaves of Magnolia grandiflora Linn were collected from the local gardens of Bangalore. The plant was authenticated by Dr. N.M Ganesh babu (Assistant professor heading centre for herbal gardens). Voucher specimen kept in the Acharya and BM Reddy college of Pharmacy, Bangalore, Karnataka, India.

\section{Extraction of plant material}

$2.5 \mathrm{~kg}$ of leaves were shade dried, coarsely powdered both leaves were extracted in Soxhlet with petroleum ether, ethyl acetate and methanol successively. After the solvents were diluted and condensed in a flash evaporator under reduced pressure, the yield was found to be $13 \mathrm{~g}, 10 \mathrm{~g}$ and $8 \mathrm{~g}$ of leaves powder respectively.

\section{Phytochemical screening}

Preliminary qualitative phytochemical tests were carried out on crude various extract employing standard procedure $^{6}$.

\section{Animals}

Adult female Swiss albino mice, weighing $20 \mathrm{~g}$ to $30 \mathrm{~g}$ were used in the study. The study protocol was reviewed and approved by the Institutional Animal Ethical Committee (IAEC No: IAEC/ABMRCP/2018-2019/22) and conforms to the Indian national science academy guidelines for the use and care of experimental animals in research. Animals were obtained from Acharya and BM Reddy College of Pharmacy, Bangalore. Mice were housed in Polyacrylic cages $(38 \times 23 \times 10 \mathrm{~cm})$ with not more than four animals per cage. They were housed in an airconditioned room and were kept in standard laboratory conditions under natural light and dark cycle and maintained humidity $60 \pm$ $5 \%$ and an ambient temperature of $25 \pm 2{ }^{\circ} \mathrm{C}$. The animals were free access to standard diet and water ad libitum. The animals were allowed to acclimatize for one week before the experiments. Commercial pellet diet contained $22 \%$ protein, $4 \%$ fat, $4 \%$ fiber, $36 \%$ carbohydrates and $10 \%$ Ash w/w supplied by Amrut rat feed, Bangalore was used. 


\section{Drugs and Chemicals}

Aspirin (Acetyl Salicylic acid), Standard drug was procured from Sigma Aldrich, India, while plants extract used as a testing group.

\section{Acute toxicity study}

The oral acute toxicity study of leaves extract of Magnolia grandiflora was evaluated according to Organization for Economic Co-operation and Development (OECD) guideline $425^{7}$ on mice (20-30 g), where the limit test dose of $2000 \mathrm{mg} / \mathrm{kg}$ was used. All the animals were kept at overnight fasting before to every experiment with free excess to water. The animals were divided into two groups, each comprising 5 animals. The $1^{\text {st }}$ group served as a control, while $2^{\text {nd }}$ was considered as tested groups received orally Magnolia grandiflora (dissolved in distilled water) extracts at dose of $300 \mathrm{mg} / \mathrm{kg}, 500 \mathrm{mg} / \mathrm{kg}$ and $2000 \mathrm{mg} / \mathrm{kg}$. Before dose administration, the body weight of each animal was determined, and the dose was calculated according to the body weight. The animals were observed for any toxic effect for first 4 hours after the treatment period. Further animals were investigated for a period of 14 days for any toxic effect ${ }^{8}$. The observations were tabulated according to 'Irwin's Table' (Table 2).

\section{Analgesic Activity by the Hot Plate Method}

Adult female Swiss albino mice were randomly grouped into five groups of six mice each, fasted for 12 hours with sufficient hygienic water provided ad libitum. Each of the mice was placed on a hot plate maintained at the temperature of $55 \pm 1^{\circ} \mathrm{C}$ and the pain reaction time (PRT) or latency period determined with a stopwatch was recorded which represents the time taken for the mice to react to the pain stimulus. The response to pain stimulus considered included jumping, raising and licking of hind foot. The cut off time was fixed for 20 seconds ${ }^{9}$. The extracts were administered I. p. 250,500 and $1000 \mathrm{mg} / \mathrm{kg}$ b. w. The mice were then treated as follows in Table 3.

Table 1: Preliminary phytochemical screening

\begin{tabular}{|c|c|c|c|}
\hline Phytoconstituents & Petroleum ether $\left(\mathbf{6 0 - 8 0} \mathbf{\circ}^{\circ} \mathbf{C}\right)$ extract & Ethyl acetate extract & Methanol extracts (70 \%) \\
\hline Steroids & + & - & + \\
\hline Triterpenoids & + & + & - \\
\hline Saponins & - & - & - \\
\hline Glycosides & + & - & - \\
\hline Carbohydrates & - & - & + \\
\hline Alkaloids & + & - & + \\
\hline Flavonoids & + & + & - \\
\hline Tannins & - & + & - \\
\hline proteins & - & - & \\
\hline
\end{tabular}

Table 2: 'Irwin's Table' of acute toxicity study

\begin{tabular}{|c|c|c|c|c|}
\hline 1. & Alertness & & $\mathrm{N}$ & $\mathrm{N}$ \\
\hline 2. & Stereotype & & $\mathrm{N}$ & $\mathrm{N}$ \\
\hline 3. & Irritability & & - & - \\
\hline 4. & Fearfulness & & - & - \\
\hline 5. & Touch response & & $\mathrm{N}$ & $\mathrm{N}$ \\
\hline 6. & Pain response & & $\mathrm{N}$ & $\mathrm{N}$ \\
\hline 7. & Spontaneous activity & & $\mathrm{N}$ & $\mathrm{N}$ \\
\hline 8. & Grooming & & - & - \\
\hline 9. & Restlessness & & - & - \\
\hline 1. & Righting reflex & \multirow{10}{*}{ 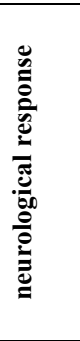 } & $\mathrm{N}$ & $\mathrm{N}$ \\
\hline 2. & Limb tone & & $\mathrm{N}$ & $\mathrm{N}$ \\
\hline 3. & Grip strength & & $\mathrm{N}$ & $\mathrm{N}$ \\
\hline 4. & Twitching & & $\mathrm{N}$ & $\mathrm{N}$ \\
\hline 5. & Abdominal tone & & $\mathrm{N}$ & $\mathrm{N}$ \\
\hline 6. & Pinna reflex & & $\mathrm{N}$ & $\mathrm{N}$ \\
\hline 7. & Corneal reflex & & $\mathrm{N}$ & $\mathrm{N}$ \\
\hline 8. & Straub tail & & - & - \\
\hline 9. & Tremors & & - & - \\
\hline 10. & Convulsions & & - & - \\
\hline 1. & Writhing & \multirow{7}{*}{ 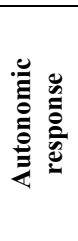 } & $\mathrm{N}$ & $\mathrm{N}$ \\
\hline 2. & Defecation & & $\mathrm{N}$ & $\mathrm{N}$ \\
\hline 3. & Urination & & $\mathrm{N}$ & $\mathrm{N}$ \\
\hline 4. & Pilo erection & & - & - \\
\hline 5. & Heart rate & & $\mathrm{N}$ & $\mathrm{N}$ \\
\hline 6. & Respiration & & $\mathrm{N}$ & $\mathrm{N}$ \\
\hline 7. & Pupil Size & & $\mathrm{N}$ & $\mathrm{N}$ \\
\hline
\end{tabular}

Table 3: Administration of the drug

\begin{tabular}{|c|c|c|}
\hline S. No. & Groups & Treatment \\
\hline 1. & control group & Normal saline $(10 \mathrm{ml} / \mathrm{kg})$ i. p. \\
\hline 2. & Standard Group & Acetyl Salicylic acid $(20 \mathrm{mg} / \mathrm{kg})$ i. p. \\
\hline 3. & Group A & Pet ether extract \\
\hline 4. & Group B & Ethyl acetate extract \\
\hline 5. & Group C & Methanol extract \\
\hline
\end{tabular}


Table 4: Administration of the drug

\begin{tabular}{|c|c|c|}
\hline S. No. & Groups & Treatment \\
\hline 1. & control group & Normal saline $(10 \mathrm{ml} / \mathrm{kg})$ i. p. \\
\hline 2. & Standard Group & Acetyl Salicylic acid $(20 \mathrm{mg} / \mathrm{kg})$ i. p. \\
\hline 3. & Group A & Pet ether extract \\
\hline 4. & Group B & Ethyl acetate extract \\
\hline 5. & Group C & Methanol extract \\
\hline
\end{tabular}

\section{Tail Immersion Method}

Adult female Swiss albino mice were randomly divided into five groups with six mice each, fasted for 12 hours with clean drinking water provided ad libitum. The animals were treated with 10 $\mathrm{ml} / \mathrm{kg}$ sodium CMC for group A (control group) for 60 minutes before tail immersion, $20 \mathrm{mg} / \mathrm{kg}$ acetyl Salicylic acid (aspirin) for group B (standard group) and 100,300 and $500 \mathrm{mg} / \mathrm{kg} \mathrm{b}$. w. of Magnolia grandiflora extract for groups C, D and E respectively. Then around 2-3 cm of each mice's tail was immersed in a water bath which containing warm water at a temperature of $50 \pm 1{ }^{\circ} \mathrm{C}$ and even the time taken for the mice to waggle its tail or remove it from the warm water documented as the pain reaction time (PRT) for every mouse. The time was recorded at every $15 \min ^{10}$. (Table 4)

\section{Data Analysis}

The result was presented as mean \pm SEM and analyzed using One-way Analysis of Variance (ANOVA). The difference between the means was tested with Dunnett's test of $\mathrm{P}<0.05$ were considered statistically significant.

\section{RESULTS}

\section{Plant Extraction}

The yield of Magnolia grandiflora leaves was found to be petroleum ether $(8.26 \%)$, ethyl acetate $(7.66 \%)$ and methanol $(6.45 \%)$ of powder extracts respectively.

\section{Phytochemicals screening}

Preliminary phytochemical tests for Petroleum ether, Ethyl acetate and Methanol extracts revealed the presence of Flavonoids, tannins and Saponins (Table 1).

\section{Acute toxicity}

The results showed no clinical signs and mortality of the animal therefore an LD50 > $2000 \mathrm{mg} / \mathrm{kg}$ body weight may be assumed.

\section{Hot Plate Method}

The result of the effect of Magnolia grandiflora leaves on the hot plate method is presented in ethyl acetate. The outcome revealed that there was no significant difference in the PRT. After standard and test drug were administered orally, by using Dunnett's test the test drugs shows better PRT with the ethyl acetate extract than petroleum ether and methanol extract $500 \mathrm{mg} / \mathrm{kg}$ than $1000 \mathrm{mg} / \mathrm{kg}$ b. w. relatively standard drug $(20 \mathrm{mg} / \mathrm{kg})$. The extract at the amount of $250 \mathrm{mg} / \mathrm{kg}$ did not illustrate any important increase in the time (Graph 1).



Graph 1: Effect of different extracts of Magnolia grandiflora on latency by Hot plate method

\section{Tail immersion method}

In Magnolia grandiflora leaves of ethanol extract, the tail withdrawal has been reported at 100,300 and $500 \mathrm{mg} / \mathrm{kg}$, i. p. Contrasted with some other two extracts at $30 \mathrm{~min}$ in mice. Data are summarized in. (Graph 2)

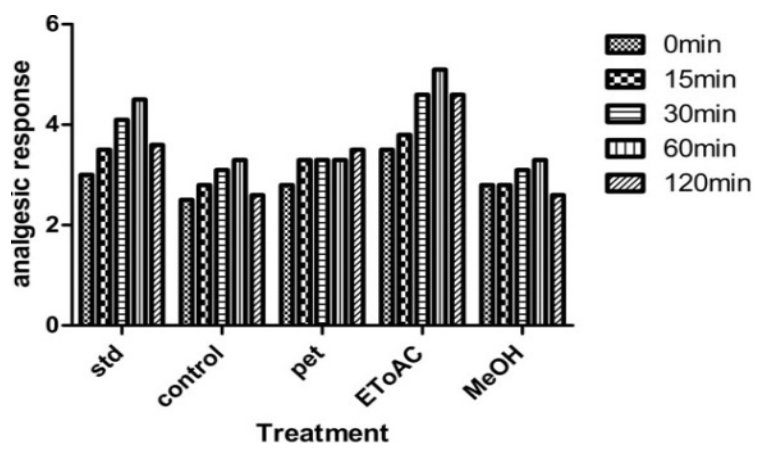

Graph 2: Effect of different extracts of Magnolia grandiflora on latency by Tail immersion method

\section{Statistical results}

Statistical analysis was done by ANOVA followed by Dunnett's test. All the values are expressed as mean $\pm \mathrm{SEM} . * \mathrm{P}<0.05,{ }^{* *} \mathrm{P}$ $<0.01$. When compared to standard drug the results of hot plate method were assessed by latency period, which showed significant $(\mathrm{P}<0.01)$ suppression of Pain reaction time of petroleum ether, ethyl acetate, extracts at a dose of $200 \mathrm{mg} / \mathrm{kg} \mathrm{b}$. w. exhibited significant $(\mathrm{p}<0.01)$ analgesic activity as compared to standard drug. Values are representing mean \pm SEM.

**P $<0.01$ as compared $(* \mathrm{P}<0.05)$ to standard indicates more significant analgesic activity. The results of central analgesic activity were assessed by tail immersion test, which showed that all these extracts show significant $(\mathrm{P}<0.01)$ analgesic activity at 30 min but ethyl acetate extract shows very moderate activity at $60 \mathrm{~min}$ compared to standard drug. 


\section{DISCUSSION}

The research was carried only due to an improvement in the intake amount of synthetic drug and its adverse effects, it is essential to reflect on herbal drug with fewer side effects. The anxiolytic effect of the plant is due to the presence of enzymes Carboxypeptidases and bradykinase which seeks to reduce anxiety. It is recognized that the plants that produce some steroidal alkaloids and earlier research have recorded coumarins to relieve pain with immunomodulatory and antioxidant properties. These seek to help alleviate anxiety by improving the immune system and reducing prostaglandins which are essential for the pain. In experimental study, analgesic effect of extract was demonstrated using the hot plate and tail immersion method. Using thermal stimuli, an increase in reaction time is generally considered an important parameter for analgesic activity. The stimulus can be thermal (tail immersion, and hot plate testing), mechanical (tail or paw pressure testing), electrical (pair, tail or dental pulp stimulation) or chemical (writhing and formalin testing). The system of hot plate immersion and tail immersion was found to be ideal for the evaluation of centrally acting analgesics.

\section{CONCLUSION}

The present study demonstrates that Magnolia grandiflora leaves extract acts as a potent analgesic agent. The analgesic activity may be due to its ability to activate Opioids receptors in the central nervous system. It may also inhibit endogenous pain substances, which are involved in the peripheral analgesia. Bioactive substances from this plant can, therefore, employed to develop drugs for the treatment of various inflammatory diseases. The petroleum ether, ethyl acetate and Methanol extracts showed pronounced analgesic effects. The data support the folk traditional use of Magnolia grandiflora to treat inflammatory diseases that are associated with pain.

\section{ACKNOWLEDGEMENTS}

We are grateful thank to Principal Acharya and BM Reddy College of Pharmacy, Bangalore. Finally, thanks for technical support by the technicians of Acharya and BM Reddy College of Pharmacy, Bangalore.

\section{REFERENCES}

1. Raylarson. Magnolias of the ARBORETUM. Washington Park Arboretum Bulletin; 2018. p. 16-19.

2. Gilman, E. F. and Watson D.G. Magnolia grandiflora: Southern Magnolia. University of Florida Institute of Food and Agricultural Sciences; 2015.

3. Schühly W, Khan I, Nikolaus H. The Ethnomedicinal Uses of Magnoliaceae from the Southeastern United States as Leads in Drug Discovery. Pharma Bio 2001; 39: 63-9.

4. El-Feraly FS, Li W-S. Phenolic constituents of Magnolia grandiflora L. seeds. Lloydia 1978; 41: 442-9.

5. Hak-Ju Lee, Khan M, Ha-Young Kang, Don-Ha Choi, Park Mi-Jin and Lee Hyun-Jung. Rare natural products from the wood of Magnolia grandiflora. Chemistry of Natural Compound 2010; 46: 2.

6. T. Thilagavathi, Vidhya Doss, Dhivya Ravichandran. Preliminary phytochemical screening of different solvent mediated medicinal plant extracts evaluated. International Research Journal of Pharmacy 2015; 6(4): 246-248.

7. Malairajan. P, Geetha Gopalakrishnan, Narasimhan S, Kala Veni K. Analgesic activity of some Indian medicinal plants Analgesic activity of some Indian medicinal plants. J Ethnopharmacology 2006; 106: 425-28.

8. Enegide Chinedu, David Arome and Fidelis Solomon Ameh. A New Method for Determining Acute Toxicity in Animal Models. Toxicol Int 2013; 20(3): 224-226.

9. Sook-Ha Fan,Noraisah Akbar Ali and Dayang Fredalina Basri. Evaluation of Analgesic Activity of the Methanol Extract from the Galls of Quercus infectoria (Olivier) in Rats. EvidenceBased Complementary and Alternative Medicine 2014; 12(2): 252-258.

10. Srinivas K Reddy, Sanjeeva A Kumar, Vinay D Kumar and S Ganapaty. Anti-inflammatory and Analgesic Activities of Amorphophallus bulbifer (Roxb) Kunth Whole Plant. Tropical Journal of Pharmaceutical Research 2012; 11(6): 971-976.

\section{Cite this article as:}

Ramyashree C and Hemalatha Kamurthy. Antinociceptive activity of Magnolia grandiflora Linn. leaves. Int. J. Res. Ayurveda Pharm. 2020;11(6):56-59 http://dx.doi.org/10.7897/ $\underline{2277-4343.1106184}$

Disclaimer: IJRAP is solely owned by Moksha Publishing House - A non-profit publishing house, dedicated to publishing quality research, while every effort has been taken to verify the accuracy of the content published in our Journal. IJRAP cannot accept any responsibility or liability for the site content and articles published. The views expressed in articles by our contributing authors are not necessarily those of IJRAP editor or editorial board members. 